Historic, Archive Document

Do not assume content reflects current scientific knowledge, policies, or practices. 



\section{SPRING PRICE}

L. IS I I

\section{FRAGARIA NURSERIES}

\section{J. FARMER, PULASKI, N. Y}

\section{SAVE TEN PER CENT BY ORDERING FROM THIS PRICE LIST SPECIAL DISCOUNT FOR CASH WITH ORDER}

We allow $10 \%$ on all orders with cash mailed before March 1st; $8 \%$ discount before April 1st; $5 \%$ before April 20th. No discount after April 20th.

In previous years, a large number of our customers have waited until late in the season to send in their orders, and this often results in disappointment for them and a congestion of business for us. For our new friends, as well as the old, we are mailing this little circular which lists in condensed form, all varieties of Trees, Shrubs, Plants and Vines, priced exactly as they will be in the new 1928 catalog. By ordering now from this list, you can take advantage of our Spacial Cash Discount, and also help us to give better service when the proper time comes to ship your order.

Note: Our new 1928 catalog is now on the press and will be mailed to you soon. This issue, we believe, will be one of the finest that we have ever mailed-with covers in color and 48 pages of illustrations and descriptions of items herein. Watch your mail for Farmer's 1928 catalog.

\section{FARMER'S SPECIAL OFFER IN ADDITION TO THE CASH DISCOUNT}

IF YOUR ORDER AMOUNTS TO $\$ 5.00$ OR MORE, WE WILL ALLOW THE REGULAR CASH DISCOUNT, AND ALSO SEND YOU FREE 1 EXCELSA RED RAMBLER, 3 YEAR; 1 HALL'S JAPAN HONEYSUCKLE VINE, 3 YEAR; 1 PURPLE JAPAN IRIS, AND 1 HOLLYHOCK.

Make out your order on the back of this sheet and fill out the coupon below.

\section{COUPON}

FRAGARIA NURSERIES, PULASki, N. Y.

My order amounts to $\$ 5.00$ or more, and I am enclosing $\$$. after deducting the regular discount. As I am taking advantage of your special offer, please include the following, free of charge, with my order. 1 Excelsa Red Rambler, 1 Hall's Japan Honeysuckle, 1 Purple Japan Iris, and 1 Hollyhock.

Name. 
Gladiolus

\section{Dahlias}

Hardy Perennials

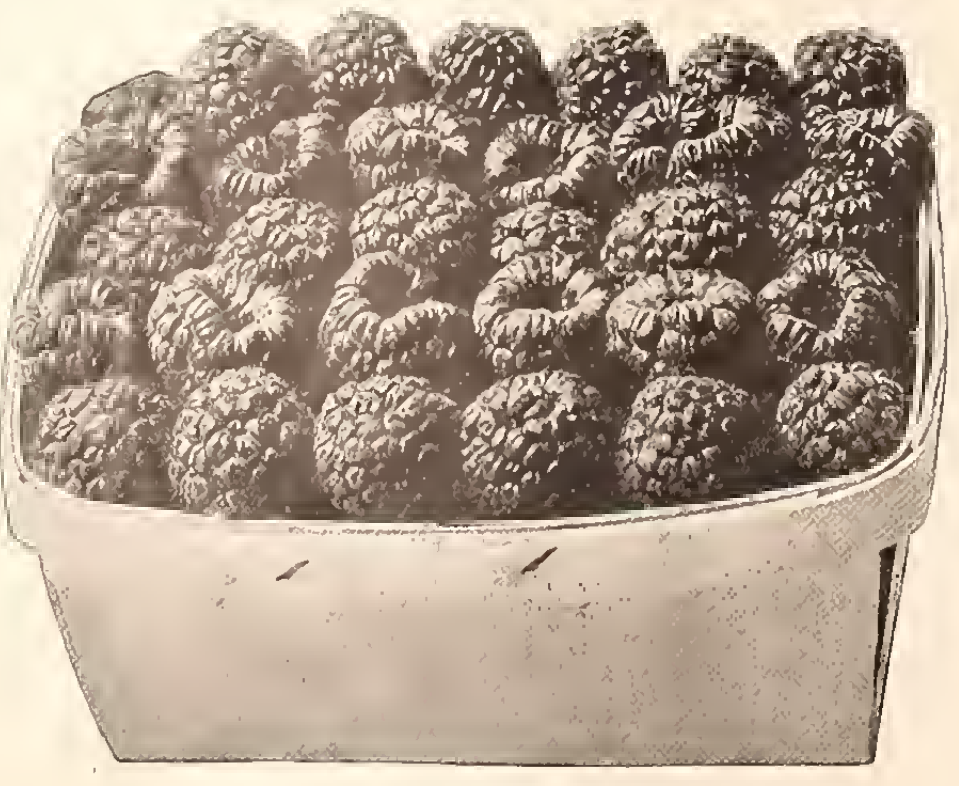

Peonies
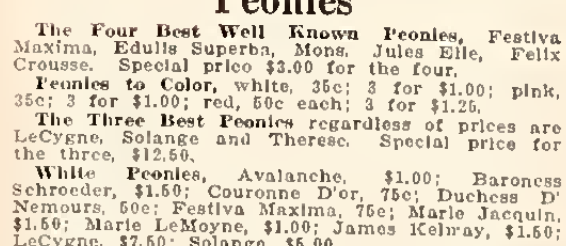

Address

"The Strawberry Man"

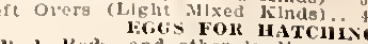
Duchs, $\$ 2,00$ per $11, \$ 8.00$ of

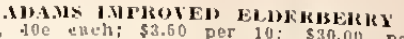
MinEse MNAMON VNE TUBERS

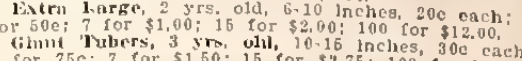
Outdoor Ferns

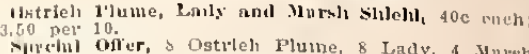
MUSMKOOM SPAW

MLWWLEX TREE PROTHCTORS HOTKA'S" FOR MLANT PHOTECTION

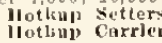
PARMME'S TALLY STTEN

MAD MADE MAKKLT BASERT

Berry Crates and Baskets

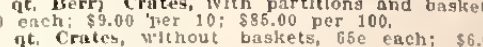

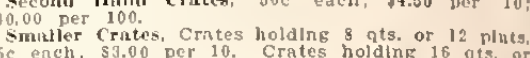

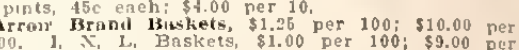

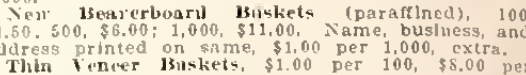
HEMOG KRM FOH C.OVER, ILFALFA, ETE Garrlen Size, for Press, Beans, of

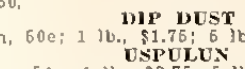
ZKLIO PASTE FOR KATS ZRLIO WHEAT FOR MOCE,
ZRT WATVEROOF AEPOSSET FLOWFK POTS

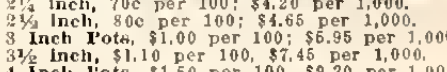

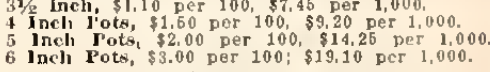

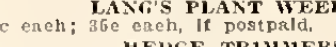
simplielty Trimmer, strou each,

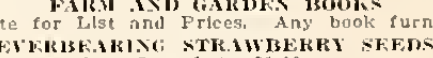
IOTITO SEEDS P'ARMFK OS THE STKAWIERKY FREE GIIT WITH EXERX ORDP

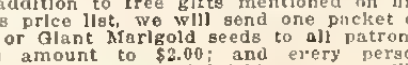

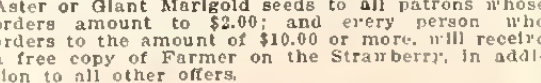

\section{J. FA R M E R}

\section{The Most Beautiful, the Most Satisfactory, the Most Economical Hedge Plant}

MANY TIMES DURING THE SEASON WE ARE ASKED, "WHAT IS THE BEST HEDGE PLANT?". ALMOST INVARIABLY WE ANSWER "JAPANESE BARBERRY", BECAUSE-

Japanese Barberry is Beautiful the Year Around

In early spring the new leaves are a soit shade of llght green $i$ in
mmer they turn to a dark glossy green summer they turn to a dark glossy green; later, as fall approaches they added by the brllliant scarlet berries, which stand out in sharp contrast agalnst the dull gray branches and the winter snow.

The Most Satisfactory Hedge Under Average Conditions

Japanese Barberry is perfectly hardy; in fact, we have never seen any indication of winter injury even to the very tlps of the young hranchlets It wy form either as at any time of the season, and may he maintained in forms a compact hedge anywhere- - or as a speclmen plant. Because it hot or cold climate, we call Japanese Barberry the World's Most Practlcal

The Most Economical Hedge for All Purposes The flrst cost is not prolihitire, and once planted a Barberry bedge will last forever, if properly maintained. It will provlde a llving fence for parks, golf links, cemeteries, and around public or prlvate properties.
it fulfills all of the requlrements of a board or iron fence, and presents a nuch nore pleasing appearance. The stiff spines on the hranches provid a barrler that will turn away the most aggressive trespassers. Japanes along the border planting on torrases or slopes in mases at corners, as a hedge along the sidewalk, driveway or property line.

Priced Low for First Quality Stock

Oul' plants are priced on a basis of quallty, age and size, and we do no pretend to meet the prices listed by some growers. Our stock is healthy to be as specified and if ln any lnstance the customer is not satlsfecl will return the full purchase price. Barberry plants should be set from 9.18 inches apart, depending upon the size that you purchase.

(PRICES ARE GIVEN UNDER "HEDGE PLANTS")

We Have Never Before Had as Nice Stock in All Grades PLACE YOUR ORDER EARLY

\section{ESTABLISHED 1883 \\ 1928 SPRING PRICE UAS FRAGARIA NURSERIES}

\author{
L. J. FARMER, PULASKI, N. Y
}

SAVE TEN PER CENT BY ORDERING FROM THIS PRICE LIST SPECIAL DISCOUNT FOR CASH WITH ORDER

We allow $10 \%$ on all orders with cash mailed before March 1 st; $8 \%$ discount be fore April 1st; $5 \%$ before April 20th. No discount after April 20th.

In previous years, a large number of our cistomers have waited until late in the season to send in thelr orders, and this often results in disappointment for them and a congestion of husiness for us. For our new friends, as well as the old, we are mailing thls little circular which lists in condensed form, all varietles of Trees, Shrubs, Plants and Vines, pricerl exactly as they will he In the new 1928 catalog. By ordering now from this list, you can take ad hantage of our Spacial Cash Discount, and also help us to give better service when the proper time conses to ship your order.

Note: Our new 1928 catalog is now on the press and will be mailed to you soon. This issue, we believe, will be one of the finest that we have ever (n) of items herein. Watch your' mail for Farmer's 1928 catalog.

\section{FARMER'S SPECIAL OFFER} IN ADDITION TO 'THE CASH DISCOUN

YOUR ORDER AMOUNTS TO $\$ 5.00$ OR MORE, WE WILL ALLOW THE REGULAR CASH DISCOUNT, AND ALSO SEND YOU FREE 1 EX CELSA RED RAMIBLER, 3 YEAR; 1 HALL'S JAPAN HONEYSUCKLE VINE, CELSA RED RAMBLER, 3 YEAR; 1 HALL'S JAPAN HON

(he coupon below.

\section{COUPON}

FRAGARIA NURSERIES, PULASK1, N. Y

My order amounts to $\$ 5.00$ or more, and I am enclosing \$..................... after deducting the regular discount. As I an taking advantage of your special offer, please Include the following, free of charge, with my order.

(This Offer Expires April 20th, 1928. 
